\title{
Students' Attitudes Toward Learning Activities Organized with the Means of WebQuest Method
}

\author{
Olga SAKADINECA, Anita JANSONE \\ Liepaja University, Liela street 14, Liepaja, Latvia \\ olgal7vsk@gmail.com, anita.jansone@liepu.lv
}

\begin{abstract}
The development of the skills and competencies of the 21 st century leads education to the need for the reform, with a view to realizing the social and economic needs of the students and the entire society of the $21 \mathrm{st}$ century. In the conditions of the transition of education to a competence approach, new means and new educational technologies based on them are needed, contributing to the improvement of the quality of education. Information and communication technologies are becoming an integral part of the educational process, qualitatively changing the information and educational environment. The technology WebQuest, as an interactive method of learning, is based on research-oriented activities with the use of the Internet resources. The article describes the techniques and methods of introducing the interactive method of learning WebQuest at the lessons of the Latvian language and literature, based on web 2.0 tools, into the learning process. One of the goals of the study was to identify students' attitudes toward learning activity using the WebQuest method. Structural components of the relationship were singled out according to the method of O. Voronina: emotional-evaluative attitude, attitude to work in the group, external and internal motivation. The article presents the results of the survey of the students of the 6th, 8th and 12th grades of Liepaja Secondary School No. 7.
\end{abstract}

Keywords: WebQuest, web 2.0 tools, students' attitude, motivation.

\section{Introduction}

Global informatization of society puts the education system in the problem of preparing the younger generation for independent decision-making and responsible decisionmaking, for life and professional activity in a highly developed information environment. Modern schoolchildren need to learn how to effectively use the opportunities of the information space, be able to defend themselves against its negative effects. The task of the school is the formation of information competence, knowledge, skills and methods of information activity that will be required by them in the future.

Forming the skills of information activity is not only the aim of the content of education, but also the teaching technologies used. One of them is the WebQuest technology. The study, mastery and application of the WebQuest method become practical in the transition of the educational process to the competence approach. The competences mastering involves active involvement of students in the educational 
process. At the same time, conditions are created for independent study of the surrounding world, for the acquisition and comprehension of new knowledge by students (Eurydice, 2012; Ponomaryeva, 2011).

The use of new forms, methods, techniques and technologies of educational process conducting, together with a competent approach, changes the role and the task of the teacher - motivating and forming a set of skills for independent activity, the teacher directs the efforts of students for self-development (Eurydice, 2012; Ponomaryeva, 2011).

One of the modern technologies that allow students to organize cognitive activity in a special way in the conditions of continuously growing amount of information and the appearance of accessible teaching Internet resources is the WebQuest technology (Klimova, 2015). The educational process built on the basis of WebQuest develops the ability of students to work both individually and in a group, as well as the ability to search information and transform it into deeper knowledge (March, 2018).

The purpose of the research was to test the application of the WebQuest method in educational activities taking the study of the Latvian language and literature as an example. In the course of this activity, an empirical study of students of the 6th, 8th and 12 th grades was conducted, and the goal of the study was to determine students' attitudes toward the learning process using the WebQuest method.

For the first time, the term WebQuest was proposed in 1995 in the United States at the University of San Diego by Professors Bernie Dodge and Tom March, working on a model of learning using the Internet resources in teaching various disciplines. According to B. Dodge, WebQuest is a research task, during which students use information obtained mainly from the Internet sources (Dodge, 1995). WebQuest, carried out mainly through the Internet resources and based on ideas of problem-project and research training, allows you to integrate a certain set of forms, methods and techniques that contribute to the development of information and analytical skills (Klimova, 2015).

The structure of the WebQuest, the requirements for its individual elements. A clear introduction, which clearly describes the main roles of the participants or the script of the quest, a preliminary work plan, a survey of the entire quest. The central task, which is understandable, interesting and feasible. The final result of independent work is clearly defined (for example, a series of questions to answer, a problem to be solved, a position to be protected, and other activities that are aimed at processing and presenting the results based on the collected information). List of information resources (links to resources on the Internet, the addresses of websites on the topic), necessary for the task. Description of the procedure of work, which must be performed for each participant of the quest for self-fulfillment of the task (stages). Description of the criteria and parameters for assessing the web quests. The evaluation criteria depend on the type of training tasks that are being addressed in the web quest. A guide to action (how to organize and present collected information), which can be presented in the form of guiding questions that organize the training work. Conclusion, which summarizes the experience that will be obtained by participants in the performance of independent work on the web-quests. Sometimes it is useful to include in conclusion rhetorical questions that stimulate the activity of students to continue their experiments in the future.

WebQuest technology has great educational and development potential for the following reasons: 
- it is a model that integrates diverse approaches, technologies, methods and procedures of teaching: problem-project training, context-based learning, communicative approach, active teaching methods, ICT;

- involves the use of a group work, which promotes the development of communicative skills and cooperation skills;

- can be used in an interdisciplinary context (Klimova, 2015).

In their practical work, the authors of the WebQuest development used the possibilities of web 2.0 tools for the lessons of the Latvian language and literature. Internet technologies, including web 2.0 tools, being an integral part of ICT, are becoming an important factor of information impact. The processes of selection, assimilation, processing, transformation and generation of information, using the Internet technologies at the lessons, allow students to develop, accept, predict and implement optimal solutions in various fields of activity (Kolesnikova, 2008). Web 2.0 tools, being the most accessible and the easiest tools to use the Internet technologies, can be the simplest way to create an electronic environment in which the teacher, as an assistant, assists in the development and the process of students'learning. Web 2.0 (blogs, wiki, on-line depositories, social networks, virtual whiteboards, mental maps, etc.) allow people to create, publish, share and also collaborate in the field of information and knowledge; this is a new way of communication and collaboration (O'Reilly, 2005).

The structure of the WebQuest elements (introduction, central task list of information resources, description of the procedure of work, description of the criteria and parameters, a guide to action, conclusion) the authors of the article formed in practice, on the basis of blogs (the Google platform), where topics, goals, objectives of the lessons were described, references to the Internet resources were pointed out, tasks with a consistent description of the work were displayed, and the names of the groups of students were defined. The students performed the assignments using web 2.0 tools - online boards, Google documents, Google forms, Google Slide, and web 2.0 service Learningapps.org. All the results of training activities of the students were integrated into the blog of WebQuest.

\section{Methodology}

The student's activity in educational activity is determined by his personal, subjective attitude towards his actions, the nature of the needs and the motivations underlying the learning activity (Osnitsky, 1992). Motivation begins with an interest, with a positive attitude towards the upcoming action. A positive attitude towards learning activity, expressed internal motivation of the student for the learning process, contributes to the successful mastery of knowledge and skills, all these features can play "the role of a compensating factor in the case of a lack of high level abilities" (Zimina, 2006).

A teacher who is interested in improving the effectiveness of his activities, draws attention to the attitude of students towards learning activities. Students are "really" included in the work, provided that the tasks set by the teacher are not only understandable, but also internally accepted (Rubenstein, 1989). Thus, the positive attitude of students towards learning activities, initiative participation in it, selfsatisfaction and their results, provide meaningful assimilation of educational material and therefore is the basis for the further development of the students (Voronina, 2008).

One of the goals of the research work was to determine students' attitudes towards learning activities organized through the WebQuest method. The attitude of students to 
learning activity is a special type of communication between the subject of learning and the activity being carried out, characterized emotionally by its acceptance and nonacceptance, with a meaningful system of motives and manifested in behavior through the results of activity (Petrovsky and Yaroshevsky, 1990). Adhering to this definition, O.A. Voronina distinguishes the following structural components of students' attitudes toward learning activity: emotional-evaluative, a system of motives and behavioral (Voronina, 2008).

To determine students' attitudes toward the learning process using the WebQuest method, students were asked to express their attitude regarding 12 judgments, which contain the structural components of the student's relationship to learning activity:

1. With such a learning model, I can learn better.

2. In the lesson, I was carried away by the task on the computer.

3. I like to perform similar assignments in a group (cooperative activity).

4. I was interested to see the work of other students.

5. This form of work allows me to show my individuality and creativity.

6. This type of training is suitable for other lessons.

7. By the use of the Internet technology learning achievement can be improved.

8. I showed diligence carrying out this task,

9. When carrying out this task, I showed perseverance.

10. While performing this task, I showed independence.

11. Carrying out this task, I showed responsibility.

12. I showed a desire and interest while carrying out this assignment,

The emotional-evaluative attitude to learning activity is characterized by the attitude to the students' own abilities - judgments $1,5,12$; the attitude to work in the group was determined by judgments 3,4 . The system of motives was revealed by judgments $2,6,7$ - external motivation through attitude to novelty and internal motivation was expressed through attitude to the quality of the work performed - judgments $8,9,10,11$.

Sixth-grade students (14 respondents), 8th grade (19) and 12th grade (8 students) were invited to evaluate the judgments on the Likert scale: 1 - "Absolutely disagree", 2 "Partially disagree", 3 - "It's difficult to say," 4 - "Partially agree," 5 - "I completely agree." When processing the results of the survey, the answers of each respondent were summarized. By the sum of the points scored, the students were divided into three types of relations to educational activity - a positive attitude, a negative and an indefinite relation in each of the components of the relationship - Table 1.

Table 1. Types of students' attitudes toward learning activities, depending on the collected scores

\begin{tabular}{|l|c|c|c|}
\hline & $\begin{array}{c}\text { Positive } \\
\text { attitude }\end{array}$ & $\begin{array}{c}\text { Indefinite } \\
\text { attitude }\end{array}$ & $\begin{array}{c}\text { Negative } \\
\text { attitude }\end{array}$ \\
\hline Emotional-estimated ratio & $>9$ points & 9 points & $<9$ points \\
\hline Attitude to group work & $>6$ points & 6 points & $<6$ points \\
\hline External motivation & $>9$ points & 9 points & $<9$ points \\
\hline Internal motivation & $>12$ points & 12 points & $<12$ points \\
\hline
\end{tabular}

Interpretation of scales:

Scale 1. "Emotionally-evaluative attitude to learning activities". The student's attitude to opportunities is an emotional-evaluative setting for the fulfillment of the 
learning task. The manifestation of a positive attitude toward one's own abilities (more than 9 points) is characterized by interest and desire to learn using the WebQuest method, which is accompanied by a positive individual attitude and development of creative abilities among students.

A low score (less than 9 points) may indicate a low interest of students in learning activities with elements of WebQuest. Students perceive the application of this method in the learning process without interest and desire, learning activity causes apathy.

Scale 2. "Attitude to work in a group." Working in a group is one of the main forms of student's activity in the learning process using the WebQuest method. Using the group work promotes the development of communicative skills and skills of cooperation. High values on this scale (above 6 points) reflect the ability of students to build interpersonal relationships in the group and the ability to cooperate, a high degree of skills of mutual learning and communication skills. The negative attitude of students to group work (less than 6 points) can be characterized by the lack of desire to perform assignments together with other students, to share their knowledge and skills, as well as inability to build communication relations in a group and distribute responsibilities.

Scale 3. "External Motivation." An important factor in the formation of attitudes toward learning is the degree of novelty in the educational process. The WebQuest model contains components such as working with a computer, the Internet technologies, which is the availability of new tools and techniques in the educational process. Positive attitude to external motives (more than 9 points) is characterized by an increased interest of students to search information on the Internet, to perform tasks using a computer, toward the very method of WebQuest.

Scale 4. "Internal Motivation". Internal motivation is manifested through the attitude towards the quality of the work performed. The positive attitude on this scale (above 12 points) is characterized by high cognitive activity in the learning process using the WebQuest method. Mastering the learning material is both the motive and the goal of learning, which is characterized by the manifestation of diligence, perseverance, independence and responsibility in the performance of the tasks.

Low scores (11 or less) characterize the insufficient importance of internal motives for students. Negative attitudes toward learning activities using the WebQuest method on this scale are manifested by a weak desire to perform tasks qualitatively, the lack of desire to achieve, a display of weak interest in success. This behavior of students may manifest low cognitive activity.

\section{Finding}

The results of the questionnaire, the aim of which is to identify attitudes toward the learning process using the WebQuest method for structural components, are presented in Table 2.

Based on the outcome of the analysis of the questionnaire results, it can be concluded that all the students in grade $6(100 \%)$ positively relate to work in the group and are internally motivated to perform tasks using the WebQuest method. At the same time only students of the 6th grade are negatively inclined to use Internet technologies in the educational process, to work with a computer - (7\% of pupils of grade 6). This can be explained by the fact that students of the 6th grade do not have enough skills and abilities to perform tasks using computer technologies, do not know how to use application programs correctly. 
Table 2. The results of the survey - the attitude of the students to the learning process using the WebQuest method (\%)

\begin{tabular}{|c|c|c|c|c|c|c|c|c|}
\hline \multicolumn{8}{|c|}{ Positive attitude (\%) } & \multicolumn{2}{c|}{ Indefinite attitude (\%) } & \multicolumn{3}{c|}{ Negative attitude (\%) } \\
\hline $\begin{array}{c}6 \\
\text { grade }\end{array}$ & $\begin{array}{c}8 \\
\text { grade }\end{array}$ & $\begin{array}{c}12 \\
\text { grade }\end{array}$ & $\begin{array}{c}6 \\
\text { grade }\end{array}$ & $\begin{array}{c}8 \\
\text { grade }\end{array}$ & $\begin{array}{c}12 \\
\text { grade }\end{array}$ & $\begin{array}{c}6 \\
\text { grade }\end{array}$ & $\begin{array}{c}8 \\
\text { grade }\end{array}$ & $\begin{array}{c}12 \\
\text { grade }\end{array}$ \\
\hline \multicolumn{8}{|c|}{ Emotional-estimated ratio } \\
\hline 78.6 & 89.5 & 87.5 & 7.1 & 0 & 0 & 14.3 & 10.5 & 12.5 \\
\hline \multicolumn{8}{|c|}{ Attitude to group work } \\
\hline 100 & 84.2 & 87.5 & 0 & 15.8 & 12.5 & 0 & 0 & 0 \\
\hline \multicolumn{8}{|c|}{ External motivation } \\
\hline 78.7 & 89.5 & 87.5 & 14.3 & 10.5 & 12.5 & 7 & 0 & 0 \\
\hline \multicolumn{8}{|c|}{ Internal motivation } \\
\hline 100 & 68.4 & 87.5 & 0 & 10.5 & 0 & 0 & 21.1 & 12.5 \\
\hline
\end{tabular}

The largest number of the students among all respondents, who negatively relate to their own abilities, also study in grade 6 (14.3\%). These students showed a negative emotional-evaluative attitude to the learning process using the WebQuest method. This attitude is manifested in the reluctance to perform tasks in a high-quality manner, which is characterized by low cognitive activity. Such low emotional-evaluative attitude of students can be explained by the fact that not all the students of the 6th grade are ready to work on computers, as a result of which there is no interest and desire to perform tasks.

The greatest number among all interviewed students who are positive about new factors in educational activity are in grade 8 (89.5\%). External motives - the performance of tasks on computers, the search for information on the Internet contribute positively to the students' own abilities. Positive emotional-evaluative attitude to the learning process using the method WebQuest was also shown by most of the students of the 8 th grade $(89.5 \%)$

The largest number of students among all respondents who have shown a negative attitude toward internal motivation $(21.1 \%$ ) also study in the 8 th grade. This attitude of the eighth graders to the learning process is natural, which is reflected in the research of psychologists. Elkonin D.B. notes that in the specified age period there is a decrease in educational internal motivation due to the increased communication with peers (Elkonin, 1995).

Students of grade 12 are the most consistent when choosing the statements of the questionnaire. In each of the categories of relations, the same results of a positive attitude were obtained $-87.5 \%$. Also, the same number of students in the 12 th grade $(12.5 \%)$ showed a negative attitude in the categories of "emotional-value attitude" and "internal motivation." The mutual influence of these categories of attitudes to the learning process is traced - an intrapersonal attitude, or an emotionally-evaluative setting of the performance of tasks directly affects the quality of work performance by the grade 12 students. 


\section{Results and Discussion}

The average values of the results of the questionnaire indicate the dominant positive attitude of students in all categories that determine the attitude of students to the learning process using the WebQuest method (see Table 3).

Table 3. The average values of the attitude of $6,8,12$ grades students to the learning process using the method WebQuest (\%)

\begin{tabular}{|l|c|c|c|}
\hline & $\begin{array}{c}\text { Positive } \\
\text { attitude }\end{array}$ & $\begin{array}{c}\text { Indefinite } \\
\text { attitude }\end{array}$ & $\begin{array}{c}\text { Negative } \\
\text { attitude }\end{array}$ \\
\hline Emotional-estimated ratio & $85.2 \%$ & $2.4 \%$ & $12.4 \%$ \\
\hline Attitude to group work & $90.6 \%$ & $9.4 \%$ & 0 \\
\hline External motivation & $85.2 \%$ & $12.5 \%$ & $2.3 \%$ \\
\hline Internal motivation & $85.3 \%$ & $3.5 \%$ & $11.2 \%$ \\
\hline
\end{tabular}

It can be seen from the table that the largest number of students - $90.6 \%$ of all respondents - positively relate to work in the group. Since the work in the groups was not of a competitive nature, then in the process of its implementation, mutual learningand the exchange of received knowledge and opinions took place. Such educational activity develops the skills of communicative abilities, cooperation and mutual learning (Shulgina, 2016).

The average indicators of the positive attitude to the learning process using the method of WebQuest in the categories of "emotional-estimated attitude", "external motivation" and "internal motivation" are also high and show 85.2\% and 85.3\% among all surveyed students. Such results of the survey allow the authors to conclude that the students evaluate the use of WebQuest technology in the educational process positively.

Positive attitude towards the teaching is characterized by the activity of students in the learning process, the ability to set long-term goals, to anticipate the results of their learning activities, to overcome difficulties in achieving the goals. The manifestation of a positive attitude toward learning activities promotes the development of positive personality traits in schoolchildren, such as activity, purposefulness, the skill of group work, an interest in carrying out different assignments.

At the same time, the use of the WebQuest method in the educational process promotes the development of critical thinking (Zhou et al., 2012), allows students to develop information and analytical skills: to search for information, analyze, synthesize, thus enhances the logical culture of students (Smirnova and Prikhodko, 2016), promotes a deeper assimilation of knowledge (Shulgina, 2016).

Investigating the possibilities of using the WebQuest method in the educational process, Klimova, Napalkov, Pervushkina note the creative rethinking of information by students, the ability to draw conclusions, express and argue their point of view (Klimova, 2015; Napalkov and Pervushkina, 2014).

Based on the main purpose of using WebQuest, which, according to B. Dodge, consists of"deep analysis of information, its processing and creating the product, which demonstrates the understanding of the material" (Dodge, 1995), we can conclude that this technology potentially contains the idea of intellectual development of students.

From the point of view of the relatively high level of students' positive attitudes towards the lessons with the use of WebQuest and taking into the account the process of 
changing of the educational paradigm in Latvia, the authors of the work consider that it's important to continue the implementation of the WebQuest method in the school curriculum.

\section{References}

Dodge B. (1995). WebQuest: a tachniquefor Internet-basedlearning. Distance Educator, 1995, no.1,2, pp.10-13.

Elkonin, D.B. (1995). Selected psychological works. Problems of Age and Pedagogical Psychology. Moscow: International Pedagogical Academy, 224 p. (published in Russian).

European Commission/EACEA/Eurydice (2012). Developing Key Competences at School in Europe: Challenges and Opportunities for Policy. Eurydice Report. Luxembourg: Publications Office of the European Union. Available: https://publications.europa.eu/en/publication-detail/-/publication/47063155-d7f7-4de8-87b08103e8b84197/language-en [viewed 01.03.2018.].

Klimova, F.B. (2015). Web Quest technology as a means of developing information and analytical skills of students in teaching English for special purposes. Northern (Arctic) Federal University (published in Russian).

Kolesnikova, V. (2008). ICT - the competence of students as the basis for the formation of a new quality of education. Available: http://26311-c002os.edusite.ru/DswMedia/iktkompetenciiuchashaixs yakakosnovastanovleniyanovogokachestvaobazovaniya.doc. [viewed 01.03.2018.].

March T. (2018). Web - Quests for Learning. Available: http:// tommarch.com/ strategies/webquests [viewed 02.01.2018].

Napalkov, S.V., Pervushkina, E.A. (2014). WEB-QUEST as a means of developing an innovative educational strategy. Privolzhsky Scientific Bulletin (Приволжский Научный Вестник), no.8 (36), part 2 - 2014, p.51-53 (published in Russian).

O'Reilly, T. (2005). What Is Web 2.0.-Design Patterns and Business Models for the Next Generation of Software. Available: http://www.oreilly.com/pub/a/web2/archive/what-isweb-20.html [viewed 14.03.2018.].

Osnitsky, A.K. (1992). Self-regulation in the professional self-determination of students. Questions of psychology. 1992. No.1-2, p.52 (published in Russian).

Petrovsky, A.V., Yaroshevsky, M.G. (1990). Psychology. Dictionary. - Moscow: Politizdat, 1990, p. 258 (published in Russian).

Ponomareva, T. (2011). Competence approach in teaching a foreign language. Modern technologies of teaching foreign languages. Materials of the scientific-practical conference, Biysk, March 24, 2011, pages 76-78 (published in Russian).

Rubenstein, S. (1989). Fundamentals of General Psychology, vol.2. M .: Pedagogika, 1989, p. 7584 (published in Russian).

Shulgina, E.M. (2016). Motivation of cognitive activity of students through the technology Web Quest. Bulletin of Tambov University. vol.21, no.5-6, p.40-45. (published in Russian).

Smirnova, O., Prikhodko, M. (2016). Development of the logical structure of students in teaching math through web quests. // Omsk Scientific Bul., no.5, p.69-71 (published in Russian).

Voronina O.A. Diagnosis of students' attitudes toward learning activity. Bulletin of Vyatka State Humanitarian University, 2008, p. 159-163 (published in Russian).

Zhou, Q., Ma, L., Huang, N., Liang, Q., Yue, H.,Peng, T. (2012). Integrating WebQuest into Chemistry Classroom Teaching to Promote Students' Critical Thinking. Creative Education, 2012, Vol.3, No.3, pp. 369-374. URL: http://www.scrip.org/journal/ce/

Zimina I.S. (2006). Motivation in the process of becoming the intellectual passionarity of students. Psychology in the university, 2006. No.4, p.50 (published in Russian).

Received June 25, 2018, revised September 7, 2018, accepted September 8, 2018 